\title{
Evidence for methane oxidation in rumen fluid in vitro
}

\author{
C Valdés 1,2, CJ Newbold 2, K Hillman 3, RJ Wallace ${ }^{2}$ \\ ${ }^{1}$ Dpto. Produccion Animal, Universidad de Leon, 24071 Leon, Spain; 2 Rowett Research Institute, \\ AB2 9SB, Aberdeen, Scotland; ${ }^{3}$ Scottish Agricultural College, AB9 1UD, Aberdeen, Scotland
}

\begin{abstract}
Although one of the major activities of the rumen fermentation is methanogenesis, some oxygen enters the rumen and it is possible that methane oxidation also occurs. Methaneutilising bacteria were isolated from the rumen (Stock and McCleskey, 1964, J Bacteriol, 88, 1071), but their role was never established. The present experiments were undertaken to evaluate the extent of methane oxidation in rumen fluid in vitro.
\end{abstract}

Rumen fluid was obtained from three canulated sheep fed a diet of hay, barley, fishmeal and molasses $(500,229.5,100,91$ and $9.5 \mathrm{~g} / \mathrm{kg}$ dry matter, respectively). Strained rumen fluid $(10 \mathrm{ml})$ plus buffer $(40 \mathrm{ml})$ was incubated with the above diet $(200 \mathrm{mg}$, ground to pass though a $1 \mathrm{~mm}$ sieve) at $39^{\circ} \mathrm{C}$ under an atmosphere of $\mathrm{CO}_{2}$ (headspace $70 \mathrm{ml}$ ) for $24 \mathrm{~h}$ and methane production was compared in the presence and absence of methylfluoride, a potent inhibitor of methane oxidation. Low additions $(4.5 \mu \mathrm{mol})$ of methylfluoride increased methane production from $373 \pm 25.2$ $\mu \mathrm{mol}$ to $403 \pm 22.0(P<0.05)$. A tenfold higher addition of methylfluoride inhibited methane production. The addition of $446 \mu \mathrm{mol}$ of ${ }^{13} \mathrm{C}$ methane, in the absence of diet or methylfluoride, resulted in the formation of 1.3 $\pm 0.1 \mu \mathrm{mol}{ }^{13} \mathrm{CO}_{2}$ (see table). The possibility that this ${ }^{13} \mathrm{CO}_{2}$ was formed by reversal of methanogenesis was eliminated by the finding that $20 \mathrm{mM}$ bromoethanosulfonic acid, an inhibitor of methanogenesis, caused only a $16 \%$ fall in the production of ${ }^{13} \mathrm{CO}_{2}$.

Thus it appears that some methane production is possible in rumen fluid, but that is unlikely to exceed $8 \%$ of net methane production.

\section{Enrichment of headspace gas after $24 \mathrm{~h}$ incubation}

$\begin{array}{lcc}\text { Addition } & \text { Atom } \%{ }^{13} \mathrm{CO}_{2} & \mu \mathrm{mol} \mathrm{of}{ }^{13} \mathrm{CO}_{2} \\ 446 \mu \mathrm{mol} \text { of }{ }^{12} \mathrm{CH}_{4} & 1.0759 & -20.64 \\ 446 \mu \mathrm{mol} \text { of }{ }^{13} \mathrm{CH}_{4} & 1.0861 & 21.96\end{array}$

The work of C Valdés was supported by a fellowship of the DGICYT of the Spanish Ministery of Education and Science. 